Arjan Qefalia*, Pleurat Rexhepi**

\title{
The Present Situation and the Future Perspectives of Foreign Direct Investment in Balkan Region
}

\section{Summary}

The past decade has witnessed increased globalization of the world economy as result of technological changes, trade liberalization and privatization policies. Balkan countries as developing nations are in the realization process of the globalization changes of the world economy. Being in the process for entry into the EU, many changes are being done to integrate with the global economic trends.

The research has shown that after the fall of communism in the 1990s the Balkan Region brought significant political and economic changes. The change in attitude led to a removal of direct blockage for FDI. As a result, continued deregulation and privatization has been widespread.

However, history of FDI is relatively short for Balkan Region in comparison with other countries. The economy opened up capital inflows only at the beginning of 1990s, and is still showing low shares in the total of Central and Eastern European flow. Despite Balkan's competitive advantage due to its geographical location and its resources, it is still far from other Central European countries in achieving the same level of FDI. This situation came as a result of: political instability, low intraregional trade, the small size of national markets, huge institutional corruption and weak judiciary system. Among the more successful Balkan recipients of FDI has been Bulgaria and Romania, while Greece has been a major source of FDI for the transition economies of the Balkan region. Greek investment is driven in part by the availability of low cost labor in the nearby transition economies.

The focus of this article is to analyze and evaluate the current performance of FDI in Balkan Region and how the governments can improve this performance.

* M.Sc., Lecturer, Faculty of Economy, University of Tirana, Albania.

** M.Sc., Lecturer, Faculty of Economy, University of Tirana, Albania. 


\section{Introduction}

There is a fundamental change arising in the world economy. The world is rapidly moving out from an environment, where national economies are isolated as self-controlled entities. Advanced technology in transportation and communication, reduced language and cultural barriers, also merging national economies into an interdependent global economic system. All components of the process are referred to as globalization.

Globalization has reduced the cost of productions in nations, where key inputs are cheap as a consequence it has increased the opportunities for companies to increase their incomes by selling around the world. Nowadays, international organizations, such as the World Trade Organization (WTO) have called for even lower barriers to cross border trade and investment.

International trade in goods and services and the increase in international production through Multinational Corporations (MNCs) have been identified as important forces of globalization.

Balkan countries as developing nations are getting aware of these important changes in the current trends for the world economy. Being in the adaptation process for entry in the EU, many transformations are being done to integrate with the global economic trends. Attracting FDI became one of the top priorities for these countries in order to diversify their economy, transfer technology, develop know-how skills, create jobs and generate growth.

They are aware of the importance of attracting FDI, but they are still far from realizing their potential. The 1990s were an important turning point for their economy due to radically changes from extreme communist isolation to free market economy. The new economic reforms considerably improved the current account balance and economic growth.

More radical reforms were made to transform the economic structure to a more outward oriented and liberalized environment. Major changes were made to FDI policies to create a more flexible, liberal and open foreign investment climate. Despite these improvements, there are many other factors that have to be considered to attract FDI and sustain a stable economic growth through it. But some countries in Balkan regions like Albania, Macedonia, and Bosnia and Herzegovina failed to attract a considerable amount of FDI for a number of reasons including chronic political instability, institutional corruption, land ownership problems and weak rule of low.

\section{FDI in Balkan region: Comparison analysis}

FDI affect the economy of the Balkan region countries in many ways, by:

- conducing accumulation of capital,

- enhancing technical knowledge and know-how,

- improving domestic competition,

- developing human resources,

- building new opportunity for employment, 
- positively affecting the balance of payments,

- increasing the level of national revenue, etc.

Despite the strong theoretical case for the advantages of free capital flows, many private capital flows pose countervailing risks. In contrast, FDI is both less volatile than other flows and has a series of additional benefits. FDI is a key factor for upgrading physical and human capital: for increasing export capacity, for reducing external vulnerability, and for boosting the structural reform momentum. FDI inflows are more likely than other forms of capital flows to translate into increases in domestic investment. FDI is a vehicle for the transfer of technology and managerial and organizational know how, and it can promote competition in the domestic market. Profits generated by FDI contribute to host country tax revenues. It has been shown that for FDI to have a significant positive impact on a host country's performance and growth the host has to already have a certain level of skills, which the Balkans countries generally possess. Finally, and crucially, the reliance on FDI is far preferable to dependence on official aid flows - this general proposition is likely to be especially important in the Balkan Region.

Investors are searching for new markets and lower cost destinations. A survey of foreign investors" intentions conducted by the consultancy AT Kearney ranked Balkan countries very high among prospective global investment destinations. The European Bank for Reconstruction and Development (EBRD) and the World Bank Business Environment and Enterprise Performance Surveys (BEEPS) appear to show that the business environment in the Balkan Region has improved significantly across almost every dimension after Kosovo war. The areas showing most improvement include infrastructure, access to finance, crime, taxation and corruption. According to the Economist Intelligence Unit's business environment assessment model, the Balkans is the sub region within Eastern Europe that is expected to see the greatest improvement in its business environment over the next five years. Of course, the recent economic improvements have not affected all countries equally, and there is considerable regional variation. Bosnia and Herzegovina and Albania, for example, are still lagging behind, as is Macedonia, which still appears to be recovering from its 2001 interethnic conflict.

The reasons for looking further south and east include: many Balkan economies have cut taxes and business environments are improving: growth rates are above central European averages, inflation has declined sharply, average monthly wages in the Balkans are half of the wages or more in Hungary, the Czech Republic and Poland, and the preferential access to EU markets enjoyed by Bulgaria, Romania and the „Western Balkans”, as well as moves to liberalize intraregional trade, are other potential attractions for foreign investors. The non EU Balkans members are not constrained by EU rules on offering special incentives to FDI.

In the Balkan region, in contrast with Central Europe, having started to privatize later there is more left to sell; there appears to be less opposition than in Central Europe; and most Balkan countries are subject to international pressure to privatize (from the multilaterals and related to their EU membership bids).

Trends demonstrate that many private investors are looking ahead, and have tended to discount the still prevalent view of prohibitive political risk in the region and daunting investment environments. The improved regional picture does not, of course, mean that 
there are not many problems still to be overcome, or that potential is being fulfilled. Foreign trade levels are still exceptionally low; and dependence on official inflows to cover very large external deficits is still high in a number of countries. Despite progress in recent years in liberalization and macroeconomic stabilization, there are still many barriers to investment in the region: a large unfinished reform agenda, bureaucracies and corruption. In particular, weak public administration is a region wide problem.

Based on businessmen's perceptions of obstacles to doing business, as well as objective indicators of the cost of regulation, corruption and red tape, the average quality of the business environment in the Balkan Region continues to lag behind the central European average, despite the recent trend of improvement in the Balkans.

Foreign investors are generally much more interested in the regional market as a whole, rather than in individual countries, which puts an onus on regional cooperation and on legal, tax, and regulatory reforms that ease doing cross border business in the region. There are acute problems to do with inordinate delays at borders and high cross border taxes. Most of the recent pick up in FDI is privatization related or oriented towards domestic markets. The region still lacks export oriented FDI, and is also not attracting sufficient greenfield investment. Most of the FDI in the Balkan region remains in low labor cost and low value added industries. However, the fact remains that recent regional output growth has been respectable, and this has been one of the few areas in the world where FDI is actually increasing.

Table 1 describes the FDI in Central, East and South Europe where the figures for Southeast Europe (Balkans) still remains low compared with other regions. In terms of cumulative FDI inflows since 1990, Central Europe has attracted five times the amount that went into the Balkan Region. But, the recent trends shows a likely medium term development in the sense that the share in the region's FDI of the leading recipients will fall over the medium term, and that of the Balkan countries will increase.

Actually, the FDI growth strategy of the new EU member states (NMS) and the Southeast European (SEE) countries is in a critical state. Excessive foreign exposure has resulted in high vulnerability, particularly of the smaller countries, and facilitated the transfer of the financial crisis. After years of continuous growth, FDI inflows to the NMS declined by $9 \%$ and to the SEE countries by $22 \%$ in 2008 (see Table 1). This was compensated by an FDI boom in the European CIS (+17\%) although mainly in the form of round-tripping Russian capital.

FDI is booming in Romania and Slovenia, with inflows reaching historical peaks respectively in 2008. This is partially due to privatization, but also to new investment projects in financial services, trade and real estate. EU membership is a stability anchor for foreign investors attracted by improving business conditions and soaring consumption. FDI contributes to the expansion of productive capacities, to efficiency improvements and also to a decline in unemployment; the foreign trade deficits of these countries, however, are still on the rise. Poland, Bulgaria and the Baltic states were hit by declines. Some of these changes were the result of normal fluctuations due to individual large investment projects. In the Czech Republic, Hungary and Slovakia, FDI inflows remained at the previous year's level and investments continued to flow also into export-oriented projects, in industries that suffered major declines of production in early 2009. 
Table 1. Overview of FDI in Central, East and Southeast Europe

\begin{tabular}{|c|c|c|c|c|c|c|c|c|}
\hline \multicolumn{9}{|c|}{ FDI inflow, EUR million } \\
\hline & 2003 & 2004 & 2005 & 2006 & 2007 & 2008 & \begin{tabular}{|c|} 
Per capita \\
inflow, EUR \\
2008
\end{tabular} & $\begin{array}{c}\text { Per capita } \\
\text { stock, EUR } \\
2008\end{array}$ \\
\hline Czech Republic & 1863 & 4007 & 9374 & 4355 & 7634 & 7329 & 703 & 7844 \\
\hline Hungary & 1889 & 3633 & 6172 & 6024 & 4429 & 4406 & 439 & 6254 \\
\hline Poland & 4067 & 10463 & 7112 & 12711 & 15352 & 10970 & 288 & 3005 \\
\hline Slovakia & 1914 & 2441 & 1952 & 3741 & 2382 & 2323 & 430 & 5700 \\
\hline Slovenia & 271 & 665 & 473 & 513 & 1050 & 1239 & 607 & 5100 \\
\hline NMS-5 & 10002 & 21200 & 25082 & 27344 & 30848 & 26266 & 398 & 4600 \\
\hline Bulgaria & 1851 & 2736 & 3152 & 6158 & 8488 & 6163 & 809 & 4293 \\
\hline Romania & 1946 & 5183 & 5213 & 9061 & 7250 & 9084 & 422 & 2402 \\
\hline Estonia & 822 & 775 & 2302 & 1432 & 1962 & 1366 & 1019 & 8690 \\
\hline Latvia & 270 & 512 & 568 & 1326 & 1648 & 916 & 404 & 3566 \\
\hline Lithuania & 160 & 623 & 826 & 1448 & 1473 & 1073 & 320 & 2722 \\
\hline NMS-10 & 15051 & 31029 & 37143 & 45152 & 49151 & 44868 & 439 & 4100 \\
\hline Albania & 158 & 278 & 213 & 259 & 481 & 682 & 215 & 935 \\
\hline Bosnia and Herzegovina & 338 & 567 & 493 & 572 & 1546 & 690 & 179 & 1400 \\
\hline Croatia & 1762 & 950 & 1468 & 2765 & 3667 & 2930 & 661 & 4930 \\
\hline Macedonia & 100 & 261 & 77 & 345 & 506 & 413 & 201 & 1600 \\
\hline Montenegro & 44 & 53 & 393 & 644 & 1008 & 832 & 1325 & 4864 \\
\hline Serbia & 1204 & 777 & 1265 & 3516 & 2272 & 1879 & 256 & 1586 \\
\hline Southeast Europe & 3606 & 2885 & 3909 & 8101 & 9480 & 7425 & 346 & 2200 \\
\hline Belarus & 152 & 132 & 245 & 282 & 1304 & 1467 & 151 & 492 \\
\hline Moldova & 65 & 121 & 153 & 200 & 360 & 484 & 136 & 509 \\
\hline Russia & 7041 & 12422 & 10366 & 23675 & 40237 & 47982 & 338 & 2500 \\
\hline Ukraine & 1260 & 1380 & 6,263 & 4467 & 7220 & 7307 & 158 & 719 \\
\hline European CIS & 8518 & 14055 & 16997 & 28624 & 49121 & 57240 & 284 & 2000 \\
\hline Total region & 27175 & 47970 & 58049 & 83494 & 110271 & 109533 & 337 & 2700 \\
\hline
\end{tabular}

Source: The Vienna Institute for International Economic Studies, 2009.

Southeast European countries in the Western Balkans received two times more FDI in 2008 than in the 2005. This is a result of increasing economic growth and progress of transformation, as well as a support to both of these processes. Large privatization projects attracted especially large amounts of FDI to Croatia, Montenegro, Bosnia\&Herzegovina and Serbia (see fig. 1) while Albania and Macedonia are lagging behind. FDI inflows in SEE have been increasing during the years (107,2\% in 2006 compared with 2005; and 17\% increase in 2007 compared with 2006; Fig. 1). But, in 2008, the Western Balkan countries (with the exception of Albania) experienced major setbacks of FDI. There is $21,6 \%$ decrease of FDI inflows in SEE in 2008 compared with 2007. The main reason for low inflows is 
Figure 1.

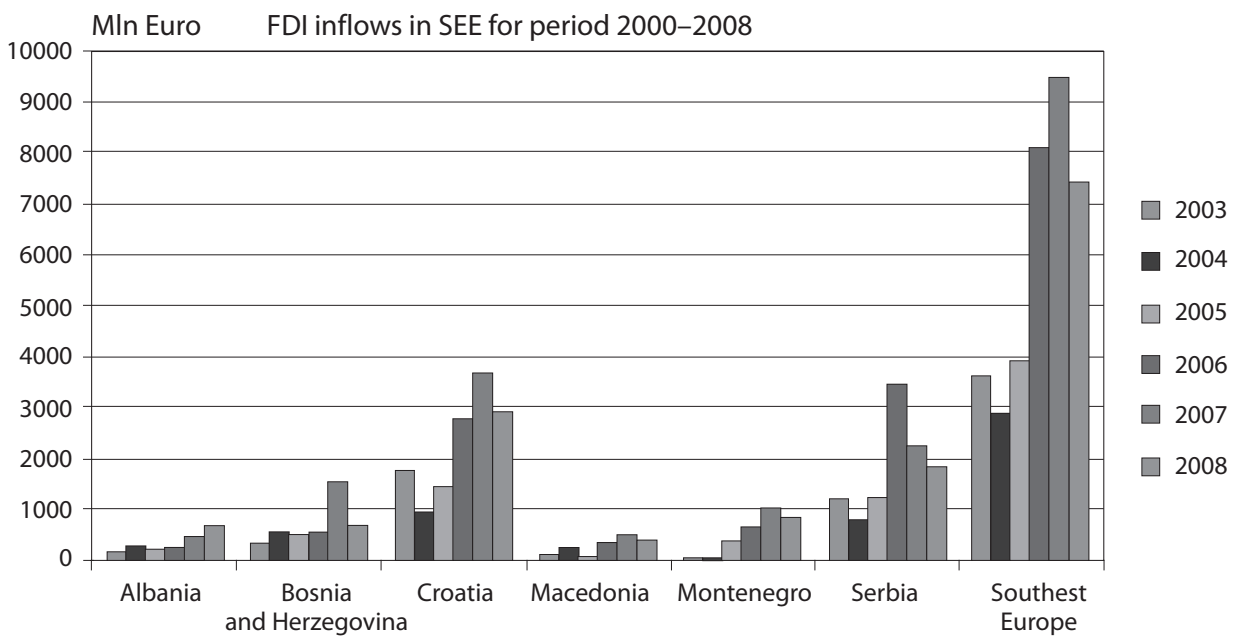

that most of the economies in the region are narrowly based and the FDI is market seeking. Investors rarely set up export-oriented projects, so the Western Balkan countries have not succeeded yet in becoming integral parts of international production networks like New Member States.

In 2009 FDI is going to contract significantly, but it will still be more resilient to the crisis than other forms of foreign investment. Large FDI inflows in the past earn high rates of income to foreign investors who repatriate a growing share of their income.

As mentioned before, the Balkan market is not enough to foster the FDI attractiveness and it is very difficult to act as a motive for foreign investors" decision. This was clearly demonstrated with the Albania, Macedonia and Bosnia Herzegovina cases. However, as can be concluded from the above table, geographical location of Balkans and close access with Western Europe and Asia markets are regarded as an important motive. In addition also the demand conditions for banking services and mobile telecommunications is a powerful incentive for foreign companies to invest in West Balkan. For instance, the majority of low income consumers of Albania, Macedonia, and Bosnia Herzegovina have a mobile phone and they tend to use the banking services to gain the remittance from their relatives. Even though it does not sound convenient, foreign firms like Vodafone and AMC have been extremely profitable in the last three years in all Balkan countries.

It is therefore wrong to make a quick judgment assuming that the market is weak and small in our region. All the foreign investors need to carefully evaluate all the business opportunities that the Balkans offers in particular sectors and never underestimate the business potentials that it can offer. 


\section{The Competetive Advantage Analysis}

In order to analyze the FDI performance of South East Europe it is recommended to undertake „The Competitive Advantage Analysis” through using Michael Porter’s Diamond Theory (Fig. 2).

Balkan countries seem to be moving in the right direction on their efforts to attract FDI but there is room for improvement. They have attracted higher FDI inflow in proportion to their gross capital formation since the mid „90s but the FDI inflows continued to remain lower compared to Central Europe. This is a significant sign that suggests us that Balkans faces serious mismanagement of the economy over a decade.

Despite the fast growing rate of the economy in the last five years, Balkans has been suffering from unstable economic and political environment for many years in the past. GDP rates have been fluctuating due to the change in political systems, conflict wars and political scandal issues.

Figure 2. Porter's Competitive Advantage of Nations. Theory adapted to Balkans

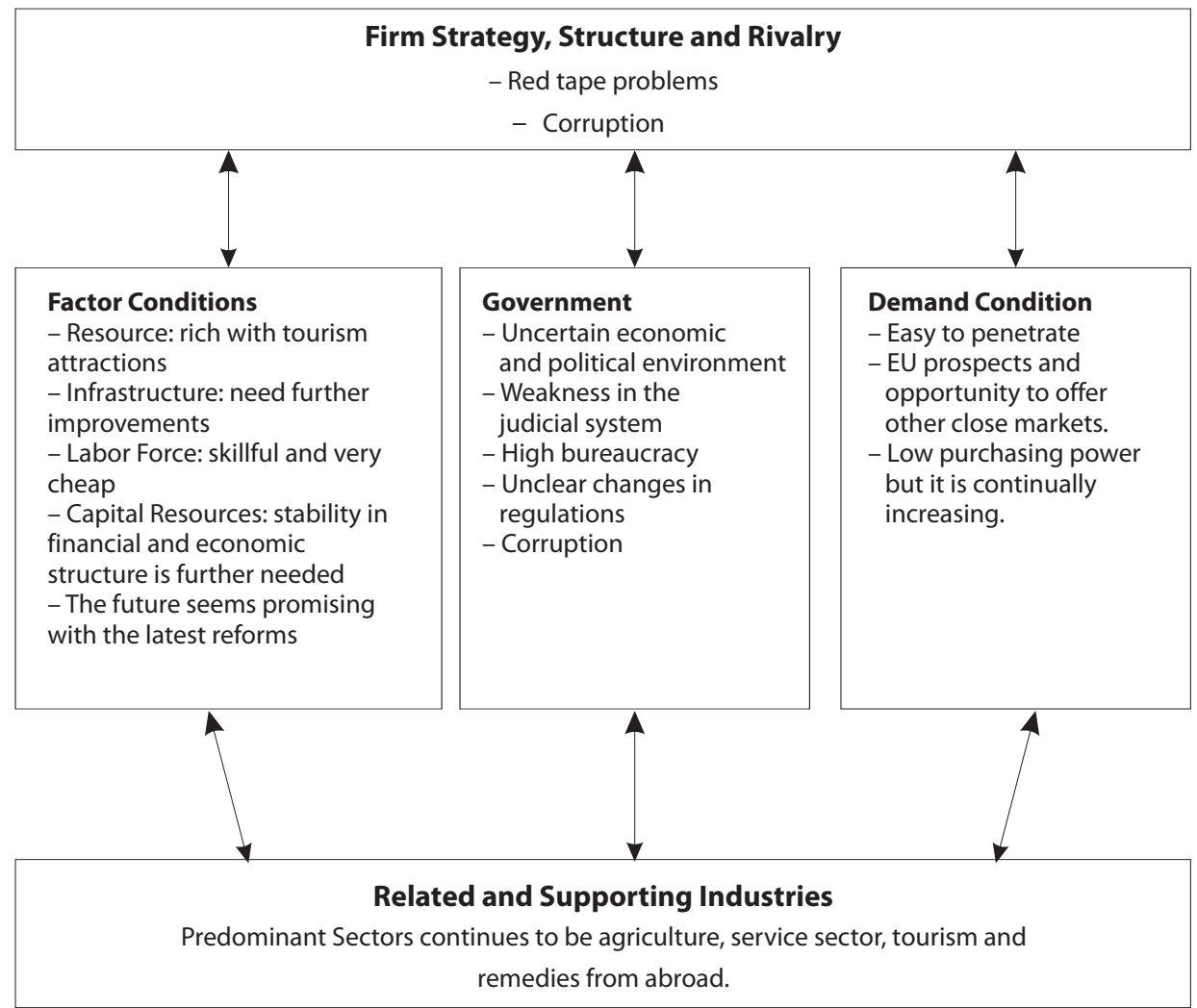

Source: Porter, 1990. 
On the other hand, a prospect success will come. Albania and Croatia membership in NATO will give a more stable environment for the future investments. As a result of the latest positive developments, the foreign investors will be more secure and the purchasing power is expected to steadily increase. These positive developments represent a better and more stable economic environment for foreign investors.

All the key informants agreed that the stability and further development of the economy and political environment towards EU are crucial for the future success of FDI. The growing market size due to further EU integration and increasing number of middle class are all positive signs for better FDI inflow. At present, Balkan region is offering comparative benefits to some other countries in Central Europe through cheaper labor force and better incentives for foreign companies. Balkan region considers foreign capital as a prior issue, therefore FDI laws have been further empowered to improve the investment climate and facilitate the process.

Referring the Porter's competitive advantage of nations, the infrastructure related issues need a special consideration in major Balkan countries especially in Albania. Energy infrastructure and telecommunication sector give the signs of urgent development. Although the Balkans labor force is regarded as being a strong factor in attracting FDI, it should be taken into account that other competitor countries can offer the same or better skilled labor force.

\section{The future of FDI in Balkan Region}

The Balkan Region is of course heavily dependent on the EU economically. Most of the Balkan countries" foreign trade is conducted with the EU and the bulk of FDI and official assistance originates from EU member countries. The Euro is legal or unofficial tender in much of the region. Remittances from EU countries are a crucial source of income and foreign exchange earnings. The EU's political influence is assured by the universal ambition in the Balkan Region to join the EU, and the EU has also assumed an increasingly important role in maintaining security in the region.

It is significant that negative assessments of the region's prospects tend to focus on the role of the EU, which is seen as absolutely crucial to the region's prospects. The EU is now said to lack a clear strategy towards the so called Western Balkans. The EU is preoccupied with its recent enlargement and own economic and other ailments. If the EU factor is seen as paramount, indeed all determining, then it is more likely that a pessimistic view will prevail.

However, it can be argued that as long as there is the prospect of eventual membership for each country in the region and that now exists the timetable may not be that important. Furthermore, in the meantime, a tight embrace by the EU may even be detrimental.

\section{Conclusions and Recommendations}

The overall picture in the Balkan Region looks more positive than in the recent past. The risk of return to major violence is low, and it has been the upsurge in foreign direct 
investment as a key signal of growing business confidence. Investors have clearly been discounting the importance of regional risk. And experience has shown the predictions made by those who risk their money tend to be the most accurate.

FDI flows to transition countries are determined by similar factors to those that govern FDI to any other area. In addition to traditional determinants such as market size, labor costs, distance and natural resource endowments, potential investment returns and costs are affected by the quality of institutions and by a wide range of policies. Among the categories that make up the overall business environment are institutional effectiveness, infrastructure and skill endowments, and macroeconomic and political stability. Also, the measurements of policies towards private enterprise in general and foreign capital in particular, as well as tax, labor market, financial sector, and foreign trade and exchange rate policies.

However, institutions may be a particularly important determinant of FDI inflows in the transition economies like Balkan countries. Foreign businesses in the region generally face transaction costs that are higher than those in mature market economies with a developed institutional framework. Foreign entrants tend to lack adequate information about their partners, and face unclear regulatory frameworks, an underdeveloped court system, and corruption.

All the bad economic results and FDI performance of Macedonia, Albania, Bosnia Herzegovina, and Serbia are related to the political instability, inherited economic structures and institutions. In many Eastern European countries severe deformation emerged under the communist rule. Capacities and capabilities were not built in situation to market demand. When liberalization came, it was a big shock as many of the old systems required structural change. Also to make the situation worse, the new market economy conditions were completely new not only for the whole country but also for the elite personalities. Basically, the Balkan free economy was built with communist mentality. This explains the massive transformation problems that Albania, Macedonia and Bosnia Herzegovina have experienced over the past decade.

Foreign investors can, to a certain extent benefit through penetrating countries with misshapen structures. This would provide them with a great advantage over domestic firms, so they could drive out any local competitors from the domestic market and introduce own manufacturing products either producing or assembling them.

Below we can find main reasons for low FDI performance and a set of recommendations for enhancing the FDI performance in Balkan countries:

\section{- Institutional Reforms:}

The political instability, transformational recession and economic performance of Balkans has left the region with poor industrial and organizational development. It is not only poverty that makes Balkan Region as developing countries but also corruption and weak governmental institutions. It is hardly possible for the market to deliver efficiency if the political and legal institutions are distorted and dysfunctional. Therefore, the first step in strengthening political and economical environment is the enforcement of Rule of Law.

\section{- Economic Structure:}

The current economic dynamics of the past four years are positive. In order to transform these dynamics into sustained growth and stability, it is very important to continue the 
ongoing institutional and economical reform process. Especially, fiscal imbalances have to be reduced and supply side policies have to be maintained. Additionally, sufficient public and private investment initiatives like education should be further implemented in order to increase the potential growth of the economy.

- The infrastructure:

Infrastructure has several weaknesses, especially energy and transport infrastructure. To meet foreign investor needs, infrastructure should be dramatically improved. New projects regarding infrastructure should be developed. The problems that are faced in strategic sectors are very serious, and in order to prevent further increasing obstacles, the infrastructure issue should be solved with the help of International Monetary Found (IMF).

\section{- Labor Force:}

The labor market should be further improved to increase the number of skilled workforce. The government can do this by developing and modernizing its educational and vocational training. In addition, business ethics courses should be included in universities to encourage the future managers in conducting a responsible business through recognition of good practices.

\section{- Legal Framework:}

The judicial system should be made independent and well functioning. Although a wide range of changes and amendments have been implemented in the process of adaptation to EU further enforcement is needed. The governments have to know that reform of the judicial system is very difficult, therefore the WB (2005) advice should be considered and legal framework should be enforced. This could be done by increasing the direct power of the market regulators and setting up arbitration institutions and administrative courts. Otherwise, late implementation of new laws and regulations will create the perception of unpredictable judicial system and it will lose the public opinion support. For this reasons, the new institutional reforms must be clear in both implementation and judicial practice.

\section{- Investment Promotion:}

The Investment Promotion Agency for Balkan Region should be established and it needs to get rid of the bureaucratic procedures. The budget should be high to improve their internal infrastructure and offer a consultancy service for the all region. A clear strategy and sector focus should be developed in order to have a planned and well functioning investment promotion agency. Furthermore, the investment incentives that are provided by governments for FDI should be reviewed so a new program can be adopted to provide more competitive incentives than Central Europe.

\section{- Research and Development:}

Balkan Region is weak in the R\&D (Research and Development) area. A program for each government should be developed to build an efficient R\&D department for the countries benefits and economic strategies. Also there should be a better incentive structure for R\&D activities comparable to other competitor countries.

\section{References}

Austria Bank, South-East Europe - A Region in Competition for FDI, Bank Austria Creditanstalt, 2004, http://www.ba-ca.com, visited on $25^{\text {th }}$ May 2006. 
Bora B., FDI Research Issues, Routledge, London 2002.

Dunning J.H., Global Capitalism, FDI and Competitiveness, Edward Elgar, Cheltenham 2002.

Mossa A., Foreign Direct Investment: Theory, Evidence and Practice, Pelgrave, Hampshire 2002.

Kekic L., FDI in the Balkans: recent trends and prospects, Economist Intelligence Unit, Eastern Europe, 2004.

OECD (2002), Trends and Recent Developments in FDI (online), available form: www.oecd.org/dataoecd/26/39/1938165.pdf, visited on 20th of May 2006.

Piggot J., Cook M., International Business Economics: A European Perspective, $2^{\text {nd }}$ edition, Prentice Hall, Essex 1999.

Porter M.E., The Competitive Advantage of Nations, Billing and Sons, Worcester 1990.

The Vienna Institute for International Economic Studies, Database on Foreign Direct Investment in Central, East and Southeast Europe, 2009

Wint A., Williams D., Attracting FDI to Developing Countries: A Changing Role for Government, „The International Journal of Public Sector Management", 2002, Vol. 15, No. 5.

\section{Stan i przyszłość bezpośrednich inwestycji zagranicznych w regionie Bałkanów}

\section{Streszczenie}

Ostatnia dekada to okres dynamicznej globalizacji gospodarki światowej wywołany głównie zmianami technologicznymi, liberalizacja handlu międzynarodowego i polityka prywatyzacji. Kraje bałkańskie sq w fazie realizacji zmian wywołanych globalizacja. Badania wykazały, że po upadku komunizmu region bałkański przeżywa znaczace zmiany polityczne i ekonomiczne. Usunięte zostały m.in. bariery realizacji bezpośrednich inwestycji zagranicznych (FDI). Wich wyniku nastapił rozwój procesu prywatyzacji.

W porównaniu z innymi krajami historia FDI w regionie bałkańskim jest stosunkowo krótka. Gospodarka krajów bałkańskich otworzyła się na międzynarodowe przypływy kapitału na poczatku lat 90. XX wieku, ale nadal cechuje się niskim udziałem w strumieniu kapitału zagranicznego napływajacego do Europy Wschodniej. Wpływ na to ma polityczna niestabilność, niski handel wewnatrz regionu, nieznaczna wielkość rynków wewnętrznych, korupcja i słaby system prawny. Głównymi odbiorcami strumienia FDI w opisywanym regionie stały się Bułgariq i Rumunia, a głównym dostawca kapitału zagranicznego-Grecja.

Artykuł koncentruje się na ocenie aktualnego stanu FDI w regionie bałkańskim i określenia perspektyw oraz możliwości wzrostu wielkości napływajacego kapitału zagranicznego do tego rejonu Europy. 